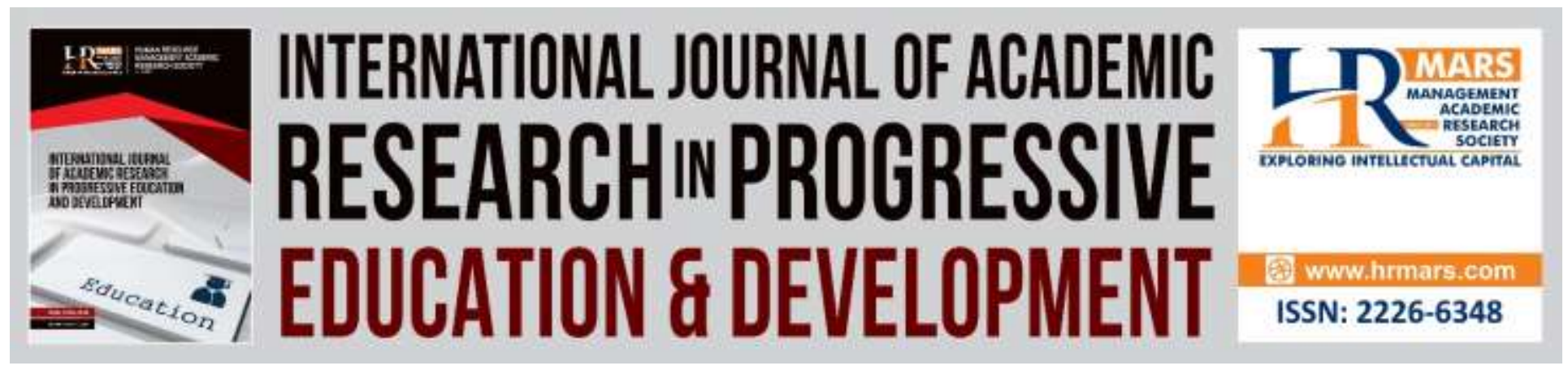

\title{
Relationship between Teachers' Perceptions Towards School Principals' Instructional Leadership Practices and Teachers' Concerns about Teaching and Learning Innovation
}

Laila Manja Mohd Yunus, Arnida Abdullah, Rosnani Jusoh

To Link this Article: http://dx.doi.org/10.6007/IJARPED/v8-i4/6432

DOI: $10.6007 /$ IJARPED/v8-i4/6432

Received: 27 July 2019, Revised: 13 August 2019, Accepted: 05 September 2019

Published Online: 16 September, 2019

In-Text Citation: (Yunus, Abdullah, \& Jusoh, 2019)

To Cite this Article: Yunus, L. M. M., Abdullah, A., \& Jusoh, R. (2019). Relationship between Teachers' Perceptions Towards School Principals' Instructional Leadership Practices and Teachers' Concerns about Teaching and Learning Innovation. International Journal of Academic Research in Progressive Education and Development, $8(4), 22-32$.

Copyright: (C) 2019 The Author(s)

Published by Human Resource Management Academic Research Society (www.hrmars.com)

This article is published under the Creative Commons Attribution (CC BY 4.0) license. Anyone may reproduce, distribute, translate and create derivative works of this article (for both commercial and non-commercial purposes), subject to full attribution to the original publication and authors. The full terms of this license may be seen at: http://creativecommons.org/licences/by/4.0/legalcode

Vol. 8(4) 2019, Pg. 22- 32

http://hrmars.com/index.php/pages/detail/IJARPED

JOURNAL HOMEPAGE

Full Terms \& Conditions of access and use can be found at http://hrmars.com/index.php/pages/detail/publication-ethics 


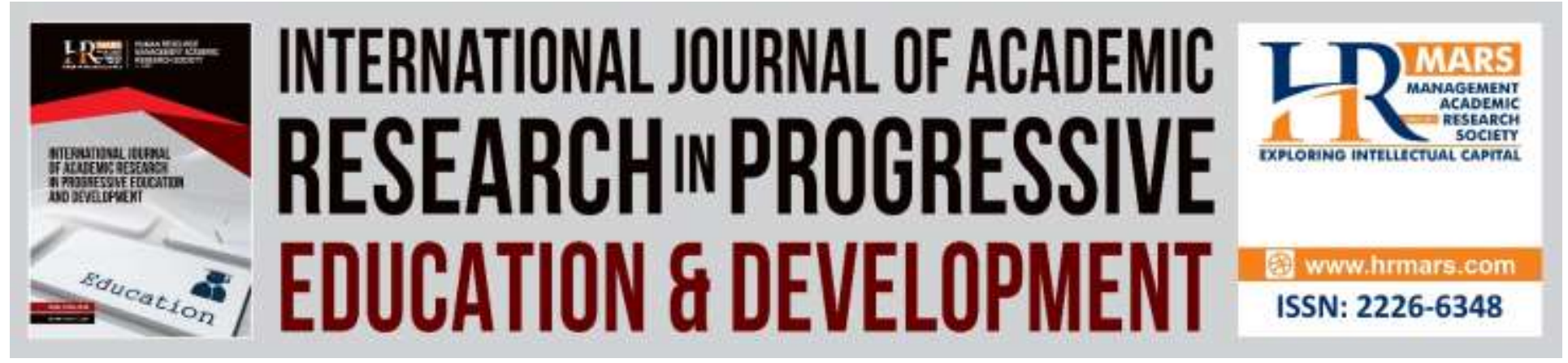

\title{
Relationship between Teachers' Perceptions Towards School Principals' Instructional Leadership Practices and Teachers' Concerns about Teaching and Learning Innovation
}

\author{
Laila Manja Mohd Yunus ${ }^{1}$, Arnida Abdullah², Rosnani Jusoh ${ }^{3}$ \\ Educational Study Faculties, Universiti Putra Malaysia
}

\begin{abstract}
The purpose of this study is to determine the relationships between secondary school teachers perceptions towards instructional leadership practices of their principals and teachers concern about teaching and learning innovation. The sample of the study consists of 350 secondary school teachers in Petaling Perdana, Selangor. The instruments were adapted from the The Principal Instructional Management Rating Scale (PIMRS) developed by Hallinger and Murphy (1985) and Stages of Concern Questionnaire (SoCQ) developed by Hall and Hord (2011). Descriptive and inferential analyses were performed to examine the relationship including frequencies, percentage, standard deviation and correlation. Data analysis indicated that there was a moderate positive correlation between teachers perceptions towards the school principal instructional leadership style and teachers concerns about teaching and learning innovation with values of $r=0.371^{* *}$ and sig $0.00(p<0.01)$. A weak relationship was found in the dimension of instructional leader's role in defining a school mission. This indicates that the principals have implemented defining a school mission dimension at weak level and significant. The finding should be given serious attention with some improvement that can be made to optimise the teachers' concerns about teaching and learning innovation.
\end{abstract}

Keywords: Instructional Leadership, Concern, Innovation, Teaching and Learning, Social Science.

\section{Introduction}

The development of a country is a reflection of the education system (Ministry of Education Malaysia, 2012), said YAB Dato' Sri Mohd Najib Tun Haji Abdul Razak, the sixth Prime Minister of Malaysia in his preliminary report on Education Development Plan 2013-2025. The aim of the Ministry of Education Malaysia (MOE) is aim to improve the quality of the education system in the 21st century to provide a generation that will face the fourth industrial revolution. This phase is based on virtual technology. School is an organization that produces intellectuals and human 
capital. The success of a school is the effort of all the school community in it. An effective leader is said to be a leader who can transform the school to a higher level and has a vision and mission (Bennis, 1985). High performing principals can increase students achievement by up to $20 \%$ (Ministry of Education Malaysia, 2012). Principals, as leaders, not only administer schools but focus on improving the quality of teaching and learning. Instructional leadership practices are said to influence school management, organization and school climate by enhancing the academic excellence of the school (Heck, Larsen, and Marcoulides, 1990; Marks and Printy, 2003; Leithwood and Mascall, 2008; Ahmed, Majid, \& Zin, (2016). For that reason, instructional leadership leaders, who focus highly on teaching and learning, are able to help teachers the current trends in education.

As an instructional leader, the principal is responsible for ensuring that all teaching and learning processes in the school are of high quality and in line with the school planning and management, in addition to establish a school culture and manage resources to build the potential for students to the highest level of school (Hallinger \& Murphy, 1985; Ahmed, Umrani, Qureshi, \& Samad, (2018). Based on the research found, two of the three most important sets of skills that link principally instructional leadership are teacher guidance and curriculum improvement. Guiding teachers by raising concerns about learning innovation supports teachers to improve school performance. Teachers' willingness to make changes or innovations in teaching and learning is crucial as quality teachers generate student excellence throughout the Ministry (Ministry of Education Malaysia, 2013). Transformation of learning in the 21st century, is studentcentered teaching and learning. Many student-centered teaching innovations are recommended for implementation in schools such as high-level thinking skills such as analyze, evaluate critically, hypothesize and make decision. The findings of effective schooling in the 1980 s especially in the United States found that principals' leadership had a significant impact on the implementation of innovation in education (Mortimore, 1995; Ahmed, Isa, Majid, Zin, \& Amin, (2017). Meanwhile, according to Laili, (2014) management style in the leadership of an organization greatly influences the development of creativity and innovation among employees.

Many of the teaching and learning innovations introduced by the MOE highlights the 21st century learning as well as the various institutions organizing the teaching and learning innovation carnival and competition. The aim is to encourage teachers to apply all teaching and learning innovations in the classroom in an effort to strengthen the national education system (Razak, Keong, \& Abdullah, 2014; Rohani \& Faizal, 2012; Rosnani \& Mashila, 2017). Weaknesses in terms of infrastructure and facilities maintenance is a phenomenon that teachers often experience in implementing innovation through the uses of (ICT) in teaching and learning process (Bayrei, 2008; Dnyaneshwar, 2011; Noraini et al., 2014). Apart from the problems faced by teachers in terms of infrastructure, a teacher innovation is also found to be at a moderate level (Noraniza's, 2013; Norliah, 2012). The study of Ghavifekar and Athiran (2015) found that the level of technology use in teaching and learning was at low level. The relationship between leadership and innovation has begun to attract the scholars. They argue that leaders can develop subordinate innovation behaviors with their leadership style (Anderson, Potocnik, \& Zhou, 2014). Previous studies have seen the relationships of principals' instructional leadership with commitment, motivation, teacher job satisfaction, PBS implementation, KSSM implementation 
and yet lack of concern towards teacher innovation. The main purpose of this study is to look at the extent to which teachers' instructional leadership relationship is related to teacher concern in implementing teaching and learning innovation.

\section{Literature Review}

Instructional leadership is defined as one that focuses on directing and instructing, creating learning communities, making decisions together, ensuring the basic things to be maintain, optimizing time use, encouraging on going staff development, managing resources that support school programs on a regular basis, creating an environment of continuous integrity (Brewer, 2001)

\section{Hallinger\& Murphy's Instructional Leadership Model (1985)}

\section{Instructionals Leadership}

\section{Defining the School Mission}

- Framing the school Goals

- Communicating the school Goals

2. Managing the instructional Program

- Coordinates the Curriculum,

- Supervising and Evaluating instruction

- Monitoring Student Progress.

\section{Promotes the School Learning Climate}

- Protecting Instructional Time,

- Providing incentives for Teacher,

- Enforcing academic standards,

- Promoting Professional Development

- Maintaining high Visibility

Figure 1: Instructional Leadership Dimension (Hallinger dan Murphy, 1985).

Figure 1 shows the dimensions of instructional leadership according to (Hallinger and Murphy, 1985) by presenting these three leadership roles in clarifying school goals, managing teaching programs and shaping a positive school climate. The first dimensions of instructional leadership that explain school goals. The principal defines the direction and goals to achieve for all members of the organization (Hallinger and Murphy, 1985). This is done to provide understanding to all teachers, students, staffs and parents according to the creativity of the principal whether through formal or informal communication.

The second dimension is managing the Teaching Program. According to Hallinger and Murphy (1985) to ensure the effective of teaching program management the principals must 
supervise and evaluate teacher's teaching in the classroom, coordinate all curriculum activities and monitor students progress so that the weaknesses can be overcome. When all activities in the academic field are aligned with the goals that lead the school to success (Hallinger and Murphy, 1985) pincipals must be fully involved in the academic development and school curriculum. Supervision of teacher innovation in the classroom should be aligned as well as principals in monitoring student achievement based on examination analysis results.

The third dimension is establishing a Positive School Learning Climate. Hallinger and Murphy emphasize the common behaviors and practices of teachers and students can influence teaching and learning. This creates a climate of inclusive learning in schools (Howard, 1987). Other elements such as preserving teaching time, providing incentives for teachers, encouraging professional development and providing incentives for student will create a school climate that promotes improved performance. Hallinger \& Heck (2011) supports the formation of a positive school climate is strongly associated with effective schools because higher levels of academic stress and competition will accompany continuous improvement. Instructional leadership should support and encourage teachers and students with incentives for the teaching and learning climate in schools.

\section{Concerns-Based Adoption Model (CBAM)}

Changes in one's behavior towards innovation in education can be measured by looking at the level of concern using the Concerns Based Adoption Model (CBAM). CBAM was found by Fuller in 1969 and has been adapted to the current situation by Hall and Hord, 2011. This model clearly identifies the level of innovation concern among teachers. CBAM is a model that can see the level of development of an individual after experiencing changes in education. Studies carried out by Chandler (2007), Hall and Hord (1984, 2001, 2006, 2011) show that recipients of change are the ones exposed to educational innovation. Recipients of change will become more familiar with an innovation.

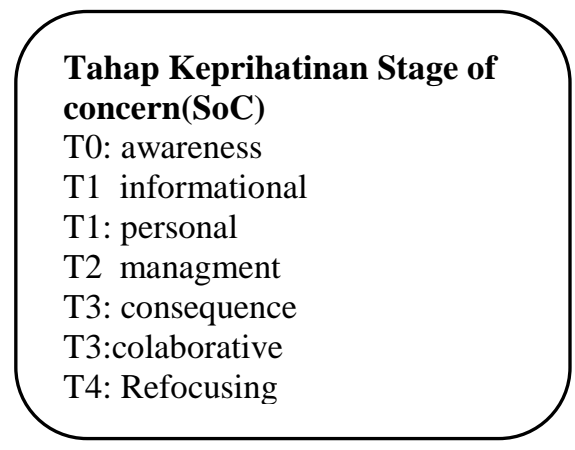

Figure 2: Stage of Concern Dimension (George, Hall, \& Stiegelbauer, 2006).

Figure 2 shows the level of concern of the recipients is described as a change in the process of current development through increasing levels of change. There are seven levels of concern based on this model ranging from awareness, information, personal, management, impact, collaborative and refocusing (George, Hall, \& Stiegelbauer, 2006). 


\section{Methodology}

This study employed quantitative correlational study. The study included a survey of a random sample of 350 teachers who had served for 3 years in daily high schools in the Petaling Perdana District, Selangor. The feedback was analyzed using the Statistical Package for Social Science (SPSS) to obtain descriptive and inferential statistics. Part A aims at obtaining respondents' demographic information such as gender, duration of service and academic background. For Part $B$ the 5-likert scale questionnaire was used which adapted from a study of Azni (2015) . Part B is a questionnaire on principal instructional leadership. Part $C$, is the 7-likert scale SoCQ Questionnaire on innovation concerns which has been adapted from Tan and Lee (2015).

The Principal Instructional Management Rating Scale (PIM,RS) by Hallinger and Murphy (1987) and translated to Malay Language. In addition, the questionnaire was sent to panel experts for content validity. The Cronbach's alpha reliability was 0.942 for instructional leadership, while SoCQ was 0.866 .

The strength of the relationships between the variables in this study was estimated using the strength scale proposed by Cohen (1988) as shown in Table 1.

Table 1: Interpretatins of Correlations by (Cohen, 1988)

\begin{tabular}{|l|l|}
\hline Correlation Coefficient $(\mathbf{r})$ & Interpretation \\
\hline .10 to .29 & Weak correlation \\
\hline .30 to .49 & Moderate correlation \\
\hline .50 to 1.0 & Strong correlation \\
\hline
\end{tabular}

\section{Analysis Data and Discussion}

The demographic characteristics of the respondents are summarized in Table 2.

Table 2: Respondents by Gender

\begin{tabular}{|l|l|l|}
\hline Gender & N & $(\%)$ \\
\hline Male & 26 & 8.0 \\
\hline Female & 296 & 92.0 \\
\hline Teaching Experience & & \\
\hline $3-6$ Years & 41 & 8.1 \\
\hline $7-10$ Years & 59 & 18.3 \\
\hline Above 11 years & 222 & 68.9 \\
\hline
\end{tabular}

8.1 percent of respondents were male teachers while 92.0 per cent were female. As much as 68.9 percent were those with more than 11 years working experience, while those with 7 to 10 years were 18.3 percent and 8.1 percent have 3 to 6 years working experience. 
INTERNATIONAL JOURNAL OF ACADEMIC RESEARCH IN PROGRESSIVE EDUCATION AND DEVELOPMENT

Vol. 8, No. 4, 2019, E-ISSN: 2226-6348 @ 2019 HRMARS

Table 3 shows the means, standard deviations and minimum and maximum values principals' instructional leadership and teachers' concerns about teaching and learning innovation.

Table 3. Descriptive Statistics

\begin{tabular}{|l|c|c|c|c|}
\hline Variable & Mean & Sd & Min & Max \\
\hline Principals' Instructional leadership & 3.82 & 0.591 & 2.09 & 5.00 \\
\hline $\begin{array}{l}\text { Teachers' concerns about teaching and } \\
\text { learning innovation }\end{array}$ & 5.06 & 0.487 & 3.83 & 6.43 \\
\hline
\end{tabular}

The Pearson's Correlation analysis was used to investigate the relationship between the variables. Table 3 provides the summary of the results obtained.

Table 4: Correlation Matrix among the Dimension of Principals' Instructional Leadership and Teachers' Concerns about Teaching and Learning Innovation

\begin{tabular}{|l|l|l|l|}
\hline \multirow{2}{*}{ Independent Variable } & \multicolumn{2}{|l|}{$\begin{array}{l}\text { Teaching and } \\
\text { learning } \\
\text { innovation }\end{array}$} & \multirow{2}{*}{ interpretation } \\
\cline { 2 - 3 } & $\mathrm{r}$ & $\mathbf{S i g .}$ & \\
\hline Defining the School Mission & $0.291^{* *}$ & 0.00 & $\begin{array}{l}\text { Positive Weak } \\
\text { correlation }\end{array}$ \\
\hline Manage school programs & $0.382^{* *}$ & 0.00 & $\begin{array}{l}\text { Negative Moderate } \\
\text { correlation }\end{array}$ \\
\hline $\begin{array}{l}\text { Creating a school-based learning } \\
\text { climate }\end{array}$ & $0.358^{* *}$ & 0.00 & $\begin{array}{l}\text { Negative Moderate } \\
\text { correlation }\end{array}$ \\
\hline $\mathbf{N}$ & $\mathbf{0 . 3 7 1 * *}$ & $\mathbf{0 . 0 0}$ & $\begin{array}{l}\text { Positive Moderate } \\
\text { correlation }\end{array}$ \\
\hline$* * p<.01$ & \multicolumn{2}{|l}{} \\
\hline
\end{tabular}

Table 4 shows that there is a significant positive relationships between the dimension determining the mission of school and principals' instructional leadership and teachers' concerns about teaching and learning innovation with values of $r=0.291$ and sig $0.00(p<0.01)$ which indicates that the strength of the relationship was weak. Next, there is a significant positive relationship between two dimensions of principals' instructional leadership (manage school programs, create a school-based learning climate) and and teachers' concerns about teaching and learning innovation. The strength of these two dimension relationship was at moderate level, $r=.382 * *$, sig $0.00(p<0.01)$ to manage school programs and $r=0.358 * *$, sig $0.00(p<0.01)$ to create a school-based learning climate. Overall, the analysis shows that there is a significant positive relationship at moderate level of teaching and learning innovation concern with the primary instructional leadership style in the secondary school with values of $r=0.371 * *$ and sig $0.00(p<0.01)$ as shown in table 4 in above. 
This is explained by the fact that any changes in instructional leadership style would result in a simple but significant linear change in teachers' teaching and learning innovation concerns. Positive relationships mean that the two variables are independent and dependent variables are related. If there is an improvement in the transformational and instructional leadership style of the principals, it will also be followed by increased concern for teacher innovation in teaching. Overall the findings shows that there is a significant relationship between instructional leadership and teaching innovation concerns despite the relationship between the two variables at a moderate level. This study is still poorly conducted by any researcher in Malaysia, so the source of reference on the study of the relationship between the instructional leadership of the Principal and the concern for teaching innovation and teacher learning is extremely limited.

The findings of the correlation analysis show a simple relationship, instructional leadership styles are important as scholars through past studies had confirmed the importance of instructional leadership in improving school performance (Cotton, 2003; Waters, Marzano \& McNulty 2005; Audryanah, 2007; Robinson et al., 2008; Azian, 2010), (Hallinger, 2011).

School performance can be enhanced by instructional leadership practices that encourage teachers to be concerned about innovation in teaching. The role of teachers' instructional leadership relationship with teaching innovation concerns involves the use of teaching and communication technology, Frog Vle, High Level Thinking Skills, Learning Centers 21st and so on. This refers to the motivation, job satisfaction and commitment of teachers to implement their teaching innovations. Positive but modest relationships show that teachers not only rely on instructional principals for innovation but there are other factors that support teachers' thinking on teaching innovation. The line of administrators consisting of senior assistant teachers, senior teachers also serve as another factor driving the teaching of teacher innovation. The burdens of the principal's leadership role and the many constraints and problems that require principals' attention make collaborative frontline administrators encourage teachers innovation in teaching to achieve school goals. Proactive teachers take the initiative to find information, materials and teaching innovations through Information and Communication Technology (ICT) that can only be obtained at the fingertip. This is a factor other than ICT facilities that can create a correlation between teachers in the same field. Noraini et al. (2013) found that factors contributing to the use of technological innovations in teaching. Amongst them are knowledge of using ICT and innovation of specialized technology information. According to Noraini et al. (2013) teachers with high levels of innovation in specializing information technology will be more rational and willing to take the risks they may face by deciding to adopt new innovations early on.

\section{Conclusion}

The findings of this study provide a clearer picture of the relationship between principals' instructional leadership and teachers' concerns about teaching and learning innovation was at a moderate level. Although the findings show a significant relationship at a moderate level, this requires principals' instructional leadership to work more closely with teachers to establish clear mission and solid strategiestor achieve goals especially in the teaching and learning aspects in classroom. Principals need to be proactive in curriculum development especially when conducting supervision and monitoring teaching. Subsequent involvement of principals in all 
school programs may further enhance their relationships with teachers teaching innovation concerns. Further research should be conducted to identify other aspects that may improve relationship between instructional leadership and teachers' concerns about teaching and learning innovation. Instructional leadership practices need to be further improved so that the high quality, innovative teaching is more likely to flourish in order to engage students in learning and to get the education system ready for the Fourth Industrial Revolution (Industry 4.0).

\section{Acknowledgement}

\section{Corresponding Author}

Laila Manja binti Mohd Yunus

Fakulti Pengajian Pendidikan, Universiti Putra Malaysia, 43400 UPM Serdang

Selangor Darul Ehsan, Malaysia

Email:ajnam69@gmail.com

\section{References}

Ahmed, U., Isa, N. M., Majid, A. H. A., Zin, M. L. M., \& Amin, B. M. (2017). Towards understanding work engagement: can HR really buffer HR? Test of a moderated model. International Journal of Economic Research, 14(20), 1-18.

Ahmed, U., Majid, A. H. A., \& Zin, M. L. M. (2016). HR Moderating HR: Critical link between Developmental HR Practices and work engagement in a Moderated Model. Management Review: An International Journal, 11(2), 4-22.

Ahmed, U., Umrani, W. A., Qureshi, M. A., \& Samad, A. (2018). Examining the links between teachers support, academic efficacy, academic resilience, and student engagement in Bahrain. International Journal of Advanced and Applied Sciences, 5(9), 39-46.

Anderson, N., Potočnik, K., \& Zhou, J. (2014). Innovation and creativity in orga- nizations: A stateof-the-science review, prospective commentary, and guiding framework. Journal of Management, 40, 1297-1333

Asrin, B. (2008). Permasalahan yang dihadapi dalam pengintegrasian teknologi maklumat dalam pengajaran bahasa di sekolah rendah. Tesis sarjana yang tidak diterbitkan. Universiti Pendidikan Sultan Idris.

Azian, A. S. (2010). Leadership Behaviour and practices of a head teacher in an excellent school.

Aziz, N. A. A. (2015). Hubungan antara kepimpinan instruksional pengetua dengan komitmen untuk perubahan guru sebagai mediator dalam melaksanakan pentaksiran berasaskan sekolah. Tesis doktor falsafah yang tidak diterbitkan. Universiti Putra Malaysia..

Bennis, W. G. \& Nanus, B. (1985). Leaders: The Strategies for Taking Charge, New York, NY:

Chandler, C. S. (2007). A Mixed Method Study on CBAM and The Adoption of Thin Client Computers By Adolescents. A Dissertation For Degree Doctor of Education, University of San Diego, San Diego.

Cohen, J. (1988) Statistical Power Analysis for the Behavioral Sciences, 2nd ed. Hillsdale, NJ: Erlbaum. Cotton,K. 2003. Principals and student achievement : What the research say. Alexandria. VA : Association for Supervision and Curriculum Developmen. 
INTERNATIONAL JOURNAL OF ACADEMIC RESEARCH IN PROGRESSIVE EDUCATION AND DEVELOPMENT

Vol. 8, No. 4, 2019, E-ISSN: 2226-6348 @ 2019 HRMARS

Dnyaneshwar, S. (2011). Use of virtual classroom in teaching through distance mode: A case study of SCDL. ELT-India. International Journal for the Teachers of English, 1(3), 35-42

Educational Administration Quarterly, 44(4), 529-561.

George, A. A., Hall, G. E., \& Stiegelbauer, S. M. (2006). Measuring Implementation in schools: The Stages Of Concern Questionnaire

Ghavifekr, S. \& Athirah, W. (2015). Teaching and learning with technology: Effectiveness of ICT integration in schools. International Journal of Research in Education and Science (IJRES), $1(2), 175-191$.

H.Heck, R., J.Larsen, T., \&A. Marcoulides, G. (1990). Instructional leadership and school

Hall, G. E., \& Hord, S. M. (2011). Implementing change: Patterns, principles, and potholes (3rd ed.). Allyn and Bacon: Pearson Education, Inc

Hallinger, P. (2011). Leadership for learning: Lesson from 40 years of empirical research. Journal of Educational Administration. 49(2), 125-142.

Hallinger, P., \& Murphy, J. (1985). Instructional Leadership and School Socio-Economic Status: A Preliminary Investigation. Administrator's Notebook. 31(5), 1-4 Harper and Row.

Howard, R. W. (1987). Concepts and shemata. Philadelphia, PA: Cassell. improvement. Educational Administration Quarterly, 26(2), 94-125. Integration of Transformational and Instructional Leadership. Educational Administration Kementerian Pendidikan Malaysia (2013).Pelan Pembangunan Pendidikan malaysia. Putrajaya. Leithwood K. \&Mascall B. (2008). Collective Leadership Effects on Student Achievement.

Marks, H. M., \&Printy, S. M. (2003). Principal Leadership and School Performance : An

Mortimore, P. (1995). The positive effects of schooling. In M. Rutter (Ed.), Psychosocial disturbances in young people: Challenges for prevention (pp. 333-363). New York, NY, US: Cambridge University Press

Noor, A. A. M. (2007). Kepimpinan pengajaran dan efikasi kendiri pengetua sekolah menengah dan hubungannya dengan pencapaian akademik sekolah. Tesis sarjana yang tidak diterbitkan. Universiti Teknologi Malaysia

Noraini, M. N,. Mahizer, H,. Norzilawati, A., Merylina, H. A. M,. Arif, D. M. I. (2014). Penggunaan Inovasi Teknologi Dalam Pengajaran: Cabaran Guru Dalam E-Pembelajaran. ads/2017/08/2014-12-Noraini-ms-172-184.pdf.

Noraini, M. N., Merylina, H. A. M., Mahizer, H., Arif, M. I., \& Norzilawati, A. (2013). Penggunaan Inovasi Teknologi dalam Pengajaran: Cabaran Guru dalam E- Pembelajaran. In Techonology Enhanced Global Classroom Enviroment (pp. 16-18). Retrieved from https://s3.amazonaws.com/academia.edu.documents/3258763/M3_-_IMETC2013__UPSI_-_Noraini__Inovasi.pdf?AWSAccesskeyld=AKIAIWOWYYGZ2Y53UL3A\&Expires=1533172761\&Signat ure=\%2FZxEuOlkYKOIg4os\%2FJ2HpnVCd0k\%3D\&response-contentdisposition=inline\%3Bfilename\%3D

Noraniza, I.(2013). Hubungan Antara Dimensi-Dimensi Kualiti Kehidupan Bekerja Guru Dengan Kesediaan Dalam Inovasi Pengajaran. Tesis sarjana yang tidak diterbitkan. Universiti Putra Malaysia 
INTERNATIONAL JOURNAL OF ACADEMIC RESEARCH IN PROGRESSIVE EDUCATION AND DEVELOPMENT

Vol. 8, No. 4, 2019, E-ISSN: 2226-6348 @ 2019 HRMARS

Norliah, M.N,. ( 2012). Inovasi pengajaran guru-guru keusahawanan dalam mata Pelajaran kemahiran hidup bersepadu (khb) sekolah menengah di Zon keramat, Kuala Lumpur. Tesis Sarjana tidak diterbitkan. Universiti Putra Malaysia.

Pallant, J. (2005). SPSS Survival Manual (2nd Edition.). Sydney: Allen \& Unwin. Quarterly, 39(3), 370-397. http://doi.org/10.1177/0013161X03253412

Razak, A. K., Keong, C. M., \& Abdullah, A. (2014). Tahap Amalan Inovasi Pengajaran Dan Pembelajaran Dalam Kalangan Guru Sekolah Agama Daerah Kuala Langat, Selangor.

Robinson, V.M.J., Lloyd, C.A., \& Rowe, K.J. (2008). The impact of leadership on student outcomes. Educational Administration Quarterly, 44(5), 635-674

Rosnah, I., \& Faizal, M. A. G. (2012). Amalan Kepimpinan Terbaik untuk Sekolah “ Organisasi Pembelajaran ". Jurnal Pendidikan Malaysia, 37(2), 35-41.

Rosnani, J., \& Mashila, N. I. (2017). Kajian terhadap pengajaran dan pembelajaran berasaskan teknologi kursus pengurusan perniagaan di kolej vokasional. International Research Journal of Education and Sciences (IRJES) eISSN 2550-2158 Vol. 1 Special Issue 1 (Malay), 2017

Tan, Y. L., \& Lee, L. W. (2015). Profil Tahap Keprihatinan Guru Terhadap Inovasi Kurikulum Standard Sekolah rendah (KSSR) Berdasarkan Model Concern-Based Adoption Model (CBAM). Diakses dari http://www.myjurnal.my/filebank/published_article/36618/ v3n3article5.pdf

Waters. T., Marzano, R., \& McNulty, B. (2004). Leadership that sparks learning. Educational Leadership, 61(1), 48-52.

Zakaria, Z. L. (2014). Semarakkan kreativiti budayakan inovasi. Bil 44/2014 Dimensi Koop.Maktab Koperasi Malaysia 